\title{
Effect of prophylactic actions on the state of oral health and hygienic habits in a selected age group
}

\author{
Paulina Wieczorek ${ }^{1, A-E}$, Marcin Rudzki ${ }^{2, B-E}$, Michał Łobacz ${ }^{3, B-E}$, Małgorzata Klichowska-Palonka, ${ }^{1, A,-F}$ \\ ${ }^{1}$ Chair and Department of Conservative Dentistry with Endodontics, Medical University, Lublin, Poland \\ ${ }^{2}$ Chair and Department of Jaw Orthopaedics, Medical University, Lublin, Poland \\ ${ }^{3}$ Chair and Department of Oral Surgery, Medical University, Lublin, Poland \\ A - Research concept and design, B - Collection and/or assembly of data, C - Data analysis and interpretation, \\ $D$ - Writing the article, E - Critical revision of the article, F - Final approval of article
}

Wieczorek P, Rudzki M, Łobacz M, Klichowska-Palonka M, Wieczorek P, Rudzki M, Łobacz, Klichowska-Palonka M. Effect of prophylactic actions
on the state of oral health and hygienic habits in a selected age group. Ann Agric Environ Med. 2018; 25(4): 642-646. doi: 10.26444/aaem/77975

\section{Abstract}

Introduction and objective. The aim of the study was investigation of the effect of simple prophylactic methods on the motivation for concern about oral hygiene among 13-15-year-olds.

Materials and method. The study covered 98 children from 4 groups attending junior high school. Adolescents from 3 groups were randomly qualified for conducting prophylactic procedures, while the fourth group constituted the control group. Three examinations were performed: preliminary and check-up examinations after 4 and 12 months. The state of the teeth and periodontium and the frequency of brushing of teeth were evaluated.

Results. After 4 months, an increase in the number of decayed teeth was observed in all groups; in the control group it was significantly higher compared to the groups subjected to prophylactic actions. After 4 months in the groups covered by prophylactic actions, a significant decrease was obtained in the number of adolescents with CPITN $>0$. In the examinations performed after 12 months, no significant differences were found in the value of the DMF and the CPITN index in the examined groups. In both examinations, after 4 and 12 months, the declared frequency of brushing teeth increased, especially in the group which had been provided individual instructions concerning oral hygiene.

Conclusions. 1) Implementation of prophylactic methods resulted in an improvement in the state of oral health among junior high school adolescents. 2) Prophylactic actions should be regularly repeated. 3) The provision of individual instruction with supervised individual teaching of brushing teeth resulted in an improvement in the motivation for concern about oral hygiene.

\section{- Key words}

DMF, CPITN, oral health promotion, oral hygiene, adolescents

\section{INTRODUCTION}

The oral cavity is an integral part of the human body, and its state exerts an effect on the general state of health, psychical and general wellbeing. Although for several years a healthpromoting life style has been popularized in the mass media, guaranteeing an attractive appearance emphasized by shining white teeth, it does not result in an increased interest in hygienic procedures [1]. Adolescents adopt superficial patterns of health-promoting behaviours from television programmes and advertisements, which are not translated into reality and adolescents' needs.

During the period of puberty, adolescents belong to a group at an increased risk of the development of caries [2]. This difficult period is frequently associated with defiance and disobedience with respect to adults. Therefore, it is especially important to provide adolescents with professional knowledge concerning the causes for the development of dental caries and periodontal diseases, and incentives for the application of prophylactic procedures [3].

Address for correspondence: Paulina Wieczorek, Chair and Department of Conservative Dentistry with Endodontics, Medical University, Lublin, Poland e-mail: paulina.stomatolog@gmail.com

Received: 25.05.2017; accepted: 25.09.2017; first published: 30.10.2017
Unfortunately, the state of oral health among adolescents still remains unsatisfactory, and nutritional habits are risky $[4,5,6]$. Motivating adolescents for care about own teeth, regular visits to a dentist, and related with it early detection and treatment of the carious foci, may exert a positive effect on the improvement of the state of oral hygiene among junior high school adolescents [7]. The objective of the study was investigation of the effect of simple prophylactic methods in an increase in motivation for care of oral hygiene among 13-15-year-olds.

\section{MATERIALS AND METHOD}

The study included 98 schoolchildren aged 13-15 attending junior high school. Those constituting the control group were selected at random, and the remaining 3 groups were also randomly ascribed various forms of prophylactic procedures. Three examinations were conducted. A preliminary examination and examination after 4 and 12 months. After completion of the preliminary examination (Examination 1) in Group 1, toothpaste with a fluoride content of 1,450 ppm was distributed, Group 2 received new toothbrushes, and in Group 3 a dentist provided individual instructions concerning oral hygiene. Group 4 constituted the control 
group. In all groups, a dentist recommended systematic brushing of teeth twice daily. After 4 (Examination 2) and 12 months (Examination 3) the state of oral hygiene and the declared frequency of brushing teeth were evaluated again. The examinations were performed in the same conditions, in the school dental room, in artificial lighting of the dental unit, using a dental mirror, explorer and periodontal probe WHO 621, maintaining the principles of asepsis and antisepsis. For the evaluation, all the tooth surfaces were dried with a stream of air from a dental unit blowpipe. In all the examined adolescents, after examinations 1,2 and 3, the state of oral health was evaluated by means of the DMFT and CPITN indices, and the declared frequency of brushing teeth.

The results were subjected to statistical analysis (ANOVA). The $\mathrm{p}$ values $\mathrm{p}<0.05$ were considered statistically significant.

\section{RESULTS}

The frequency of caries in the studied population in the preliminary examination was $92.57 \%$, after 4 months it increased to $94.90 \%$, and after 12 months up to $96.94 \%$.

Table 1. DMF number and $\mathrm{D}$ and $\mathrm{F}$ components in Group 1

\begin{tabular}{|c|c|c|c|c|c|c|c|c|c|}
\hline D number & $N$ & $M$ & Me & Min & Max & Q1 & Q3 & $S D$ & $\begin{array}{l}\text { Significance of } \\
\text { differences }\end{array}$ \\
\hline Examination 1 & 25 & 2.72 & 2.0 & 0 & 8 & 1.0 & 4.0 & 2.44 & \multirow{3}{*}{$\begin{array}{l}\text { Chi }^{2} \text { ANOVA } \\
(\mathrm{N}=25 . \mathrm{df} 2) \\
=10.305 \mathrm{p}=0.006 \\
\mathrm{I}-\mathrm{III}\end{array}$} \\
\hline Examination 2 & 25 & 2.84 & 2.0 & 0 & 9 & 1.0 & 5.0 & 2.76 & \\
\hline Examination 3 & 25 & 3.56 & 3.0 & 0 & 11 & 2.0 & 4.0 & 2.74 & \\
\hline number & $N$ & $M$ & Me & Min & Max & Q1 & Q3 & $S D$ & $\begin{array}{l}\text { Significance of } \\
\text { differences }\end{array}$ \\
\hline Examination 1 & 25 & 1.32 & 1.0 & 0 & 6 & 0.0 & 2.0 & 1.82 & \multirow{3}{*}{$\begin{array}{l}\text { Chi }^{2} \text { ANOVA } \\
(\mathrm{N}=25 . \mathrm{df} \\
2)=16.213 \\
\mathrm{p}=0.0003 \\
\mathrm{I}-\mathrm{III}\end{array}$} \\
\hline Examination 2 & 25 & 1.68 & 1.0 & 0 & 6 & 0.0 & 3.0 & 1.80 & \\
\hline Examination 3 & 25 & 2.44 & 2.0 & 0 & 6 & 1.0 & 4.0 & 2.04 & \\
\hline DMF number & $N$ & $M$ & Me & Min & Max & Q1 & Q3 & $S D$ & $\begin{array}{l}\text { Significance of } \\
\text { differences }\end{array}$ \\
\hline Examination 1 & 25 & 4.04 & 3.0 & 0 & 13 & 2.0 & 6.0 & 3.43 & \multirow{3}{*}{$\begin{array}{l}\text { Chi' }{ }^{2} \text { ANOVA } \\
(\mathrm{N}=25 . \mathrm{df} 2) \\
=28.964 \mathrm{p}<0.001\end{array}$} \\
\hline Examination 2 & 25 & 4.52 & 3.0 & 0 & 13 & 2.0 & 7.0 & 3.62 & \\
\hline Examination 3 & 25 & 6.00 & 6.0 & 0 & 13 & 3.0 & 8.0 & 3.62 & \\
\hline
\end{tabular}

Table 3. DMF number and D and F components in Group 3

\begin{tabular}{|c|c|c|c|c|c|c|c|c|c|}
\hline D number & $N$ & $M$ & Me & Min & Max & Q1 & Q3 & $S D$ & $\begin{array}{l}\text { Significance of } \\
\text { differences }\end{array}$ \\
\hline Examination 1 & 24 & 3.83 & 3.0 & 0 & 13 & 2.0 & 5.5 & 3.33 & \multirow{3}{*}{$\begin{array}{l}\text { Chi }^{2} \text { ANOVA } \\
(\mathrm{N}=24 . \mathrm{df} 2) \\
=11.104 \mathrm{p}=0.004\end{array}$} \\
\hline Examination 2 & 24 & 4.13 & 3.5 & 0 & 11 & 2.0 & 6.5 & 3.26 & \\
\hline Examination 3 & 24 & 4.50 & 4.0 & 0 & 11 & 3.0 & 6.0 & 3.01 & \\
\hline F number & $N$ & $M$ & Me & Min & Max & Q1 & Q3 & $S D$ & $\begin{array}{l}\text { Significance of } \\
\text { differences }\end{array}$ \\
\hline Examination 1 & 24 & 1.50 & 1.5 & 0 & 4 & 0.0 & 2.5 & 1.35 & \multirow{3}{*}{$\begin{array}{l}\text { Chi }^{2} \text { ANOVA } \\
(\mathrm{N}=24 . \mathrm{df} 2) \\
=13.378 \mathrm{p}=0.001\end{array}$} \\
\hline Examination 2 & 24 & 1.71 & 1.0 & 0 & 6 & 1.0 & 3.0 & 1.43 & \\
\hline Examination 3 & 24 & 2.50 & 2.0 & 0 & 16 & 1.0 & 3.0 & 3.19 & \\
\hline DMF number & $N$ & $M$ & Me & Min & Max & Q1 & Q3 & $S D$ & $\begin{array}{l}\text { Significance of } \\
\text { differences }\end{array}$ \\
\hline Examination 1 & 24 & 5.33 & 4.5 & 0 & 17 & 2.5 & 8.0 & 3.87 & \multirow{3}{*}{$\begin{array}{l}\text { Chi }^{2} \text { ANOVA } \\
(\mathrm{N}=24 . \mathrm{df} 2) \\
=33.475 \mathrm{p}<0.001\end{array}$} \\
\hline Examination 2 & 24 & 5.83 & 5.0 & 0 & 17 & 3.0 & 8.0 & 3.93 & \\
\hline Examination 3 & 24 & 7.00 & 6.5 & 1 & 19 & 4.0 & 9.5 & 4.23 & \\
\hline
\end{tabular}

Tables 1,2, 3, 4, present the results of clinical examinations concerning the condition of teeth in individual groups. In the preliminary examination, the mean value of the number of decayed teeth (D) was in Group 1-2.72; Group 2-3.36; Group 3-3.83; and in Group 4-3.86, respectively (Tabs. 1-4). In the examination performed after 4 months, an increase in the number of decayed teeth was observed in all groups; however, in the control group it was significantly higher statistically, compared to the groups subjected to prophylactic actions $(\mathrm{p}<0.05)$. Twelve months after performance of the preliminary examination, in all the groups in the study a statistically significant increase was noted in the number of decayed teeth $(\mathrm{p}<0.05)$ (Tabs. $1-4)$.

The mean number of filled teeth $(\mathrm{F})$ also increased between the examinations. In Examination 1, the mean $\mathrm{F}$ number was: in Group 1-1.32; Group 2-2.14; Group 3-1.50; and in the control group - 1.81. In Groups 1 and 2, a statistically significant increase in the number of fillings was observed between Examinations 1 and $3(\mathrm{p}<0.05)$. In Group 3, a statistically significant increase in the $\mathrm{F}$ number was found between Examinations 2 and 3 ( $\mathrm{p}<0.05)$. In the control group, the values of $\mathrm{F}$ component increased in time; however, these

Table 2. DMF number and D and F components in Group 2

\begin{tabular}{|c|c|c|c|c|c|c|c|c|c|}
\hline D number & $N$ & $M$ & Me & Min & $\operatorname{Max}$ & Q1 & Q3 & $S D$ & $\begin{array}{l}\text { Significance of } \\
\text { differences }\end{array}$ \\
\hline & & 3.36 & 3.0 & 0 & 10 & 1.0 & 5.0 & 2.80 & \multirow{3}{*}{$\begin{array}{l}\text { Chi }^{2} \text { ANOVA } \\
(\mathrm{N}=28 . \mathrm{df} 2) \\
=13.2607 \mathrm{p}=0.001\end{array}$} \\
\hline amination 2 & 28 & 3.71 & 3.0 & 0 & 10 & 2.0 & 5.5 & 2.77 & \\
\hline ramination 3 & 28 & 4.21 & 4.0 & 0 & 11 & 2.5 & 6.0 & 3.01 & \\
\hline & $N$ & $M$ & Me & Min & $\operatorname{Max}$ & Q1 & Q3 & $S D$ & e of \\
\hline & 28 & 2.14 & 2.0 & 0 & 7 & 1.0 & 3.5 & 1.92 & \multirow{3}{*}{$\begin{array}{l}\text { Chi }^{2} \text { ANOVA } \\
(\mathrm{N}=28 . \mathrm{df} 2) \\
=12.103 \mathrm{p}=0.002\end{array}$} \\
\hline Examination 2 & 28 & 2.39 & 2.0 & 0 & 9 & 1.0 & 4.0 & 2.22 & \\
\hline Examination 3 & 28 & 3.00 & 3.0 & 0 & 11 & 1.0 & 4.0 & 2.54 & \\
\hline & $N$ & $M$ & Me & Min & $\operatorname{Max}$ & Q1 & Q3 & $S D$ & $\begin{array}{l}\text { Significance of } \\
\text { differences }\end{array}$ \\
\hline Examination 1 & 28 & 5.61 & 5.5 & 0 & 15 & 4.0 & 7.5 & 3.55 & \multirow{3}{*}{$\begin{array}{l}\text { Chi }^{2} \text { ANOVA } \\
(\mathrm{N}=28 . \mathrm{df} 2) \\
=37.081 \mathrm{p}<0.001 \\
\text { |-II. II-III. I-III }\end{array}$} \\
\hline Examination 2 & 28 & 6.21 & 6.0 & 0 & 15 & 4.0 & 8.0 & 3.49 & \\
\hline Examination 3 & 28 & 7.32 & 7.5 & 0 & 16 & 4.5 & 9.0 & 3.89 & \\
\hline
\end{tabular}

Table 4. DMF number and D and F components in control group

\begin{tabular}{|c|c|c|c|c|c|c|c|c|c|}
\hline D number & $N$ & $M$ & Me & Min & Max & Q1 & Q3 & $S D$ & $\begin{array}{l}\text { Significance of } \\
\text { differences }\end{array}$ \\
\hline Examination 1 & 21 & 3.86 & 3.0 & 0 & 12 & 1.0 & 5.0 & 3.62 & \multirow{3}{*}{$\begin{array}{l}\text { Chi }{ }^{2} \text { ANOVA } \\
(\mathrm{N}=21 . \mathrm{df} 2) \\
=10.073 \mathrm{p}=0.007\end{array}$} \\
\hline Examination 2 & 21 & 4.67 & 5.0 & 0 & 12 & 2.0 & 6.0 & 3.32 & \\
\hline Examination 3 & 21 & 4.62 & 5.0 & 0 & 12 & 2.0 & 6.0 & 3.57 & \\
\hline F number & $N$ & $M$ & Me & Min & Max & Q1 & Q3 & $S D$ & $\begin{array}{l}\text { Significance of } \\
\text { differences }\end{array}$ \\
\hline Examination 1 & 21 & 1.81 & 1.0 & 0 & 5 & 0.0 & 3.0 & 1.86 & \multirow{3}{*}{$\begin{array}{l}\text { Chi' }{ }^{2} \text { ANOVA } \\
(\mathrm{N}=21 . \mathrm{df} 2) \\
=7.722 \mathrm{p}=0.021\end{array}$} \\
\hline Examination 2 & 21 & 1.90 & 2.0 & 0 & 5 & 0.0 & 3.0 & 1.70 & \\
\hline Examination 3 & 21 & 2.29 & 2.0 & 0 & 6 & 1.0 & 3.0 & 2.00 & \\
\hline DMF number & $N$ & $M$ & Me & Min & Max & Q1 & Q3 & $S D$ & $\begin{array}{l}\text { Significance of } \\
\text { differences }\end{array}$ \\
\hline Examination 1 & 21 & 5.67 & 5.0 & 1 & 13 & 4.0 & 8.0 & 3.28 & \multirow{3}{*}{$\begin{array}{l}\text { Chi }{ }^{2} \text { ANOVA } \\
(\mathrm{N}=21 . \mathrm{df} 2) \\
=20.450 \\
\mathrm{p}=0.00004 \\
|-| I .|-| I \mid\end{array}$} \\
\hline Examination 2 & 21 & 6.57 & 6.0 & 1 & 13 & 5.0 & 8.0 & 3.04 & \\
\hline Examination 3 & 21 & 6.95 & 6.0 & 1 & 15 & 5.0 & 8.0 & 3.50 & \\
\hline
\end{tabular}


differences were on the threshold of statistical significance $(\mathrm{p}=0.021)($ Tabs. 1-4).

The mean value of the DMF index (Examination $1 \mathrm{DMF}$ =5.15; Examination $2 \mathrm{DMF}=5.77$; Examination $3 \mathrm{DMF}$ $=6.83$ ) increased by 1.68 within the period of one year (Examinations 1 and 3). The mean DMF number in the preliminary examination in Group 1 was 4.04, Group 2-5.61, Group 3-5.33, and in Group 4-5.67. Between the preliminary examination and check-up Examination 2, a statistically significant increase was observed in the mean DMF number in Groups 1, 2 and $4(\mathrm{p}<0.05)$. The check-up examination performed 12 months after the preliminary examination indicated a statistically significant increase in the mean DMF number in all the studies groups $(\mathrm{p}<0.05)$ (Tabs. 1-4).

The state of periodontium was evaluated using the CPITN index. The results obtained in the clinical study were ascribed into 2 categories: 0 - adolescents with a healthy periodontium, and $>0$ - adolescents in whom the CPI $=1$ or $C P I=2$ code was found in at least one sextant. In the control examination, after 4 months, in Groups 1, 2, and 3, the number of adolescents with CPITN $>0$ decreased, compared to the preliminary examination, and the difference was statistically significant $(\mathrm{p}<0.05)$ (Tab. 5). In Examination 3, in Groups 2 and 3, the number of adolescents with CPITN $>0$ significantly increased

Table 5. Evaluation of the state of periodontium in individual groups in Examinations 1 and 2

\begin{tabular}{|c|c|c|c|c|}
\hline \multicolumn{2}{|c|}{ Study group } & $\begin{array}{c}\text { Adolescents in } \\
\text { whom improvement } \\
\text { was observed after } 4 \\
\text { months }\end{array}$ & $\begin{array}{c}\text { Adolescents in } \\
\text { whom deterioration } \\
\text { was observed after } 4 \\
\text { months }\end{array}$ & Statistical analysis \\
\hline \multirow{2}{*}{ Total } & $\mathbf{N}$ & 33 & 9 & \multirow{2}{*}{$\begin{array}{c}\mathrm{Chi}^{2}=12.595 . \mathrm{df}=1 \\
\mathrm{p}=0.0004\end{array}$} \\
\hline & $\%$ & $33.67 \%$ & $9.18 \%$ & \\
\hline \multirow{2}{*}{ Group 1} & $\mathbf{N}$ & 9 & 1 & \multirow{2}{*}{$\begin{array}{c}C h i^{2}=4.900 . d f=1 \\
p=0.027\end{array}$} \\
\hline & $\%$ & $36.00 \%$ & $4.00 \%$ & \\
\hline \multirow{2}{*}{ Group 2} & $\mathbf{N}$ & 7 & 0 & \multirow{2}{*}{$\begin{array}{c}C h i^{2}=5.143 . d f=1 \\
p=0.023\end{array}$} \\
\hline & $\%$ & $25.00 \%$ & $0.00 \%$ & \\
\hline \multirow{2}{*}{ Group 3} & $\mathbf{N}$ & 15 & 3 & \multirow{2}{*}{$\begin{array}{c}C h i^{2}=6.722 . d f=1 \\
p=0.010\end{array}$} \\
\hline & $\%$ & $62.50 \%$ & $12.50 \%$ & \\
\hline \multirow{2}{*}{ Group 4} & $\mathbf{N}$ & 2 & 5 & \multirow{2}{*}{$\begin{array}{c}\mathrm{Chi}^{2}=0.571 . \mathrm{df}=1 \\
\mathrm{p}=0.450\end{array}$} \\
\hline & $\%$ & $9.52 \%$ & $23.81 \%$ & \\
\hline
\end{tabular}

Table 6. Evaluation of the state of periodontium in individual groups in Examinations 2 and 3

\begin{tabular}{|c|c|c|c|c|}
\hline \multicolumn{2}{|c|}{ Study group } & $\begin{array}{l}\text { Adolescents } \\
\text { in whom } \\
\text { improvement was } \\
\text { observed between } \\
\text { Examinations } 2 \text { and } 3\end{array}$ & $\begin{array}{c}\text { Adolescents in } \\
\text { whom deterioration } \\
\text { was observed } \\
\text { between } \\
\text { Examinations } 2 \text { and } 3\end{array}$ & Statistical analysis \\
\hline \multirow{2}{*}{ Total } & $\mathbf{N}$ & 6 & 30 & \multirow{2}{*}{$\begin{array}{l}\text { Chi }^{2}=14.694 . d f=1 \\
p=0.0001\end{array}$} \\
\hline & $\%$ & $6.12 \%$ & $30.61 \%$ & \\
\hline \multirow{2}{*}{ Group 1} & $\mathbf{N}$ & 2 & 7 & \multirow{2}{*}{$\begin{array}{l}\mathrm{Chi}^{2}=1.778 . \mathrm{df}=1 \\
\mathrm{p}=0.182\end{array}$} \\
\hline & $\%$ & $8.00 \%$ & $28.00 \%$ & \\
\hline \multirow{2}{*}{ Group 2} & $\mathbf{N}$ & 1 & 10 & \multirow{2}{*}{$\begin{array}{l}\mathrm{Chi}^{2}=5.818 . \mathrm{df}=1 \\
p=0.016\end{array}$} \\
\hline & $\%$ & $3.57 \%$ & $35.71 \%$ & \\
\hline \multirow{2}{*}{ Group 3} & $\mathbf{N}$ & 0 & 12 & \multirow{2}{*}{$\begin{array}{l}\mathrm{Chi}^{2}=10.083 . \mathrm{df}=1 \\
\mathrm{p}=0.002\end{array}$} \\
\hline & $\%$ & $0.00 \%$ & $50.00 \%$ & \\
\hline \multirow{2}{*}{ Group 14} & $\mathbf{N}$ & 3 & 1 & \multirow{2}{*}{$\begin{array}{l}C h i^{2}=0.250 . d f=1 \\
p=0.617\end{array}$} \\
\hline & $\%$ & $14.29 \%$ & $4.76 \%$ & \\
\hline
\end{tabular}

statistically, compared to Examination 2 (Tab. 6). Twelve months after performing the preliminary examination, no statistically significant differences were found in the value of the CPITN index in the examined groups (Tab. 7).

Table 7. Evaluation of the state of periodontium in individual groups in Examinations 1 and 3

\begin{tabular}{|c|c|c|c|c|}
\hline \multicolumn{2}{|c|}{ Study group } & $\begin{array}{l}\text { Adolescents in whom } \\
\text { improvement of } \\
\text { result was observed } \\
\text { after } 12 \text { months }\end{array}$ & $\begin{array}{c}\text { Adolescents in whom } \\
\text { deterioration of result } \\
\text { was observed after } 12 \\
\text { months }\end{array}$ & Statistical analysis \\
\hline \multirow{2}{*}{ Total } & $\mathbf{N}$ & 19 & 19 & \multirow{2}{*}{$\begin{array}{l}\text { Chi }{ }^{2}=0.026 . d f=1 \\
p=0.871\end{array}$} \\
\hline & $\%$ & $19.39 \%$ & $19.39 \%$ & \\
\hline \multirow{2}{*}{ Group 1} & $\mathbf{N}$ & 6 & 3 & \multirow{2}{*}{$\begin{array}{l}\mathrm{Chi}^{2}=0.444 . \mathrm{df}=1 \\
p=0.505\end{array}$} \\
\hline & $\%$ & $24.00 \%$ & $12.00 \%$ & \\
\hline \multirow{2}{*}{ Group 2} & $\mathbf{N}$ & 4 & 6 & \multirow{2}{*}{$\begin{array}{l}\mathrm{Chi}^{2}=0.100 . \mathrm{df}=1 \\
\mathrm{p}=0.752\end{array}$} \\
\hline & $\%$ & $14.29 \%$ & $21.43 \%$ & \\
\hline \multirow[b]{2}{*}{ Group 3} & $\mathbf{N}$ & 6 & 6 & \multirow{2}{*}{$\begin{array}{l}\mathrm{Chi}^{2}=0.0833 \\
\mathrm{df}=1 \\
\mathrm{p}=0.773\end{array}$} \\
\hline & $\%$ & $25.00 \%$ & $25.00 \%$ & \\
\hline \multirow{2}{*}{ Group 4} & $\mathbf{N}$ & 3 & 4 & \multirow{2}{*}{$\begin{array}{l}\text { Chi }^{2}=0.000 . d f=1 \\
p=1.000\end{array}$} \\
\hline & $\%$ & $14.29 \%$ & $19.05 \%$ & \\
\hline
\end{tabular}

Table 8. Declared frequency of brushing of teeth in Groups 1, 2, 3, and 4

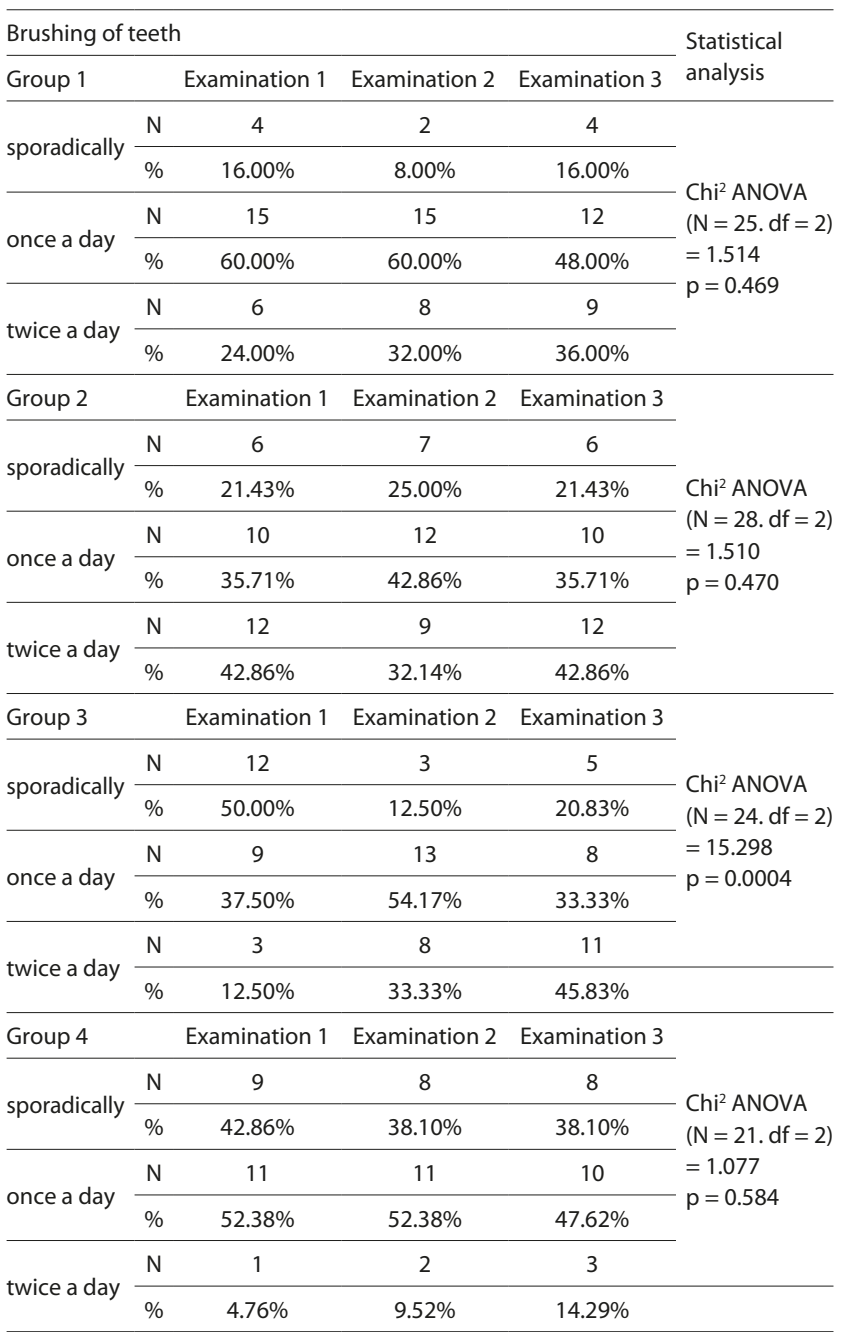


In the preliminary examination, $31.63 \%$ adolescents declared that they brushed their teeth sporadically; $45.92 \%$ once a day, and only $22.45 \%$ twice a day. Only in Group 3 a statistically significant increase was observed in the frequency of brushing teeth after 4 and 12 months. In the preliminary examination, $12.5 \%$ of adolescents brushed their teeth twice a day, in Examination 2-33.33\%, and in Examination 3-45.83\%. In the remaining groups, an increase in the frequency of brushing teeth was also noted; however, the differences were statistically insignificant (Tab. 8).

\section{DISCUSSION}

The state of oral health in adolescents aged $13-15$ is unsatisfactory. Monitoring studies conducted in the whole of Poland confirm a high percentage of dental caries typical of this age group $[8,9,10]$. In the presented study, the frequency of caries among junior high school adolescents was high; in preliminary examination it was $92.57 \%$, and after 12 months increased up to $96.94 \%$. Late detected and untreated caries constitute a great problem and is the cause of the premature loss of teeth among children and adolescents. The premature loss of teeth in adolescence results in an impairment in the function of the masticatory apparatus, as well as an aesthetic defect.

Oral diseases, to a considerable extent, depend on life style, mode of nutrition and hygienic habits. Studies show that adolescents possess satisfactory knowledge concerning the causes of development of dental caries, principles of healthy eating, and hygienisation procedures; however, this knowledge is not applied in practice $[11,12,13,14]$. The todate system of prophylaxis and education of both parents and adolescents is ineffective. In order to change this situation it is recommended to constantly increase activity in the sphere of health education and oral cavity prophylaxis among adolescents, as well as their parents $[15,16]$.

In the check-up examination performed among junior high school adolescents 4 month after the implementation of prophylactic action, the number of decayed teeth (D) increased in all groups in the study; however, this increase was statistically significant only in the control group, i.e. the group without prophylactic actions. Within the interval of one year from the implementation of prophylaxis, a significant increase in the number of D was noted in all groups. Information concerning prophylaxis provided by a dentist in the dental surgery may change the healthpromoting behaviours of adolescents for several months. The number of fillings significantly increased statistically in the groups covered by prophylactic actions. In the control group, where exclusively the examination of the state of oral health was performed, an increase in the number of fillings between examinations was on the threshold of significance. It may be presumed that adolescents encouraged by a dentist to care for own teeth, more willingly reported for treatment.

In Group 3, where during the preliminary visit an individual oral hygiene instruction was provided, after 4 months the lowest increase in the mean DMF number was observed. Regular, frequent visits to a dentist in combination with education may result in an improvement of the state of dentition in adolescents. Imparting reliable knowledge and individual instruction concerning oral hygiene allow the understanding of the importance of the effect of observing hygiene on the state of oral health $[15,17]$. Studies conducted by Axelsson showed that systematically provided instruction in oral hygiene, within a short period of time, may result in a considerable reduction of caries, even by $90 \%[15,18]$. Studies indicated that more frequent visits to a dentist may correlate with more frequent brushing of teeth by adolescents [15]. It was observed that in the groups where prophylactic actions were applied, adolescents were better motivated and more frequently reported for treatment.

Studies conducted by Urbaniak indicated that $89.5 \%$ of the examined adolescents required an improvement in the frequency and effectiveness of hygienic procedures, and $59.7 \%$ the removal of tartar [19]. In the preliminary own examination it was found that $37.76 \%$ of the adolescents required the performance of scaling $(\mathrm{CPITN}=2)$. After 4 months, the number of adolescents with CPITN $>0$ decreased. The prophylactic actions performed motivated adolescents for the removal of tartar. After 12 months, a smaller number of adolescents required the removal of tartar, compared to the preliminary examination; nevertheless, an increase was observed in the number of those in whom it was necessary to improve the effectiveness of cosmetic procedures.

In Group 3, where the dentist provided individual instruction concerning oral hygiene, the number of adolescents after 4 and after 12 months. Einwag et al., in their study noted a positive effect of supervised brushing of teeth on the improvement of the state of oral hygiene in adolescents [20]. The current study, similar to other studies, shows that the direct patient-dentist communication may be one of the most effective methods for the improvement of oral hygiene and health promoting behaviours [21, 22].

\section{CONCLUSIONS}

1. Implementation of simple prophylactic methods may result in an improvement in the state of oral health among junior high school adolescents.

2. Prophylactic actions should be regularly repeated.

3. The provision of individual instruction concerning oral hygiene with teaching the brushing of teeth supervised by a dentist, exerts a special effect on the improvement of adolescents' motivation to care for oral hygiene.

\section{REFERENCES}

1. Składnik-Jankowska J, Kaczmarek U. Dental Status and Treatment Needs in Children and Young Adults from Lower Silesia Region. Dent Med Probl. 2012; 49: 173-183.

2. Ito A, Hayashi M, Hamasaki T, Ebisu E. Risk assessment of dental caries by using Classification and Regression Trees. J Dent. 2011; 39: 457-463.

3. Marinho V, Chong LY, Worthington H, Walsh T. Fluoride mouthrinses for preventing dental caries in children and adolescent. Cochrane Database Syst Rev. 2016 doi: 10.1002/14651858.CD002284.

4. Małkiewicz K, Kępa J. Caries Prevalence and Malocclusion of 15Year-Old Schoolchildren of Mazowieckie Province. Dent Med Probl. 2012; 49: 189-194.

5. Söderström U, Johansson I, Sunnegårdh-Grönberg K. A retrospective analysis of caries treatment and development in relation to assased caries risk an adult population in Sweden. BMC Oral Health 2014; 14:126 doi: 10.1186/1472-6831-14-126.

6. Llena C, Leyda A, Forner L, Garcet S. Association between the number of early carious lesions and diet in children with a high prevalence of caries. Eur J Pediatr Dent. 2015; 16: 7-12.

7. Ito A, Hayashi M, Hamasaki T, Ebisu E. How regular visit and preventive programs affect onset of adult caries. J Dent Res. 2012; 91: 52S-58S. 
8. Pawka B, Dreher P, Herda J, Szwiec I, Krasicka M. Dental caries in children as a social problem. Probl Hig Epidemiol. 2010; 91: 5-7.

9. Jodkowska M, Oblacińska A, Tabaka I. How well do Polish teenagers meet health behavior guidelines? Przegl Epidemiol. 2014; 68: 147-151.

10. Strużycka I, Wierzbicka M, Jodkowska E, Rusyan E. Results of nationwide epidemiological surveys of oral health in young adults in Poland in 2012. Nowa Stomatol. 2013; 4: 195-199.

11. Miernik M, Paszkiewicz A. Questionnaire Study on Basic Denta Knowledge Among Teenagers. Dent Med Prob. 2009; 46: 83-87.

12. König KG. Diet and oral health. Int Dent J. 2000; 50:162-74.

13. Bachanek T, Hopkała M, Chałas R, Klijer M, Pawłowicz A. Questionnaire survery. Dental awareness in 15-year olds regarding dental hygiene. Mag Stomatol. 2003; 13: 66-68.

14. Perkowska M, Wochna-Sobańska M. Caries intensity in 12-year-old children as related to hygienic and dietary habits. J Stomatol. 2013; 4: 454-463.

15. Marcinkowski JT, Świderska J. Compliance with oral hygiene and its impact on sustaining oral cavity health. Hygeia Public Health 2011; 46: $83-88$.
16. Wdowiak L, Szymańska J, Mielnik-Błaszczak M. Selected dentistry problems: the public health aspect. Zdr Publ. 2003; 113: 308-311.

17. Szczurek D. Evaluating efficacy of selected programs for prophylaxis of caries and periodontal diseases in school children with special reference to guidelines for oral cavity hygiene. Ann Acad Med Stetin. 1996; 42: 223-235.

18. Axellson P. The effect of a plaque control programme on gingivitis, periodontis and dental caries. Akademish avhandling Gotenberg 1978: 15.

19. Urbaniak B. Health behaviour and the state of the periodontium among adolescents from high schools in Łódź. Stomat Współ. 2000; 2: 35-39.

20. Einwag J, Henkel R, Dohler B. Wpływ środków zapobiegawczych na zdrowie jamy ustnej młodzieży w wieku 14-16 lat. Mag Stomatol. 2007; 17: 102-104

21. Chachra S, Dhawan P, Kaur T, Sharma AK. The most effective and essential way of improving the oral health status education. J Indian Soc Pedo Prev Dent. 2011; 3: 26-221.

22. Fratila A, Pitica AE, Fleancu A. Dentist software application in children caries prophylaxis. Rev Sercet Interv S. 2013; 41: 118-128. 